Wright State University

CORE Scholar

Finance and Financial Services Faculty

Publication

Finance and Financial Services

$12-2004$

\title{
Errors \& Omissions Insurance: The Experience of States with Mandatory Programs for Real Estate Licensees
}

James E. Larsen

Wright State University - Main Campus, james.larsen@wright.edu

Joseph Coleman

Wright State University - Main Campus, joseph.coleman@wright.edu

Follow this and additional works at: https://corescholar.libraries.wright.edu/finance

Part of the Finance and Financial Management Commons

\section{Repository Citation}

Larsen, J. E., \& Coleman, J. (2004). Errors \& Omissions Insurance: The Experience of States with Mandatory Programs for Real Estate Licensees. .

https://corescholar.libraries.wright.edu/finance/6

This Report is brought to you for free and open access by the Finance and Financial Services at CORE Scholar. It has been accepted for inclusion in Finance and Financial Services Faculty Publication by an authorized administrator of CORE Scholar. For more information, please contact library-corescholar@wright.edu. 


\title{
Errors \& Omissions Insurance: The Experience of States with Mandatory Programs for Real Estate Licensees
}

\author{
Research Report Submitted to the: \\ Ohio Department of Commerce, Division of Real Estate \& Professional Licensing
}

December, 2004

\author{
James E. Larsen, Ph.D. \\ Professor, Finance and Financial Services \\ Raj Soin College of Business \\ Wright State University \\ Dayton, Ohio 45435 \\ Phone: (937) $775-2870$ \\ Fax: (937) 775-3545 \\ Email: james.larsen@wright.edu
}

Joseph W. Coleman, Ph. D.

Associate Professor, Information Systems and Operations Management

Raj Soin College of Business

Wright State University

Dayton, Ohio 45435

Phone: (937) 775-2648

Fax: (937) 775-3545

Email: joseph.coleman@wright.edu 


\section{Errors \& Omissions Insurance: The Experience of States with Mandatory Programs for Real Estate Licensees}

\section{Contents}

Title

Page

List of Exhibits

ii

Executive Summary

1. Introduction 1

2. OAR REALTOR ${ }^{\circledR}$ Member Survey 3

3. States with Mandatory E\&O Programs 5

4. The Licensees Perspective 7

5. Analysis of Licensee Survey Data 18

6. The Regulators Perspective 23

6.1. Motivations for Mandatory E\&O 23

6.2. Satisfaction with Mandatory E\&O 25

6.3. Advantages and Disadvantages of Mandatory E\&O 26

6.4. Program Administration 31

6.5. Policy Terms \& Associated Regulations 32

6.6. Recent Claim Activity 36

7. Implementation of Mandatory E\&O: Lessons from Existing Programs 38

$\begin{array}{ll}\text { References } & 40\end{array}$ 


\section{Errors \& Omissions Insurance: The Experience of States with Mandatory Programs for Real Estate Licensees}

\section{$\underline{\text { List of Exhibits }}$}

$\begin{array}{lll}\text { Number Title } & \text { Page }\end{array}$

1 Location of States with Mandatory E\&O

2 Twelve States with Mandatory E\&O 6

3 Licensee Years in Real Estate 8

4 Licensee Response to Three Survey Questions 10

$5 \quad$ Number of E\&O Claims Filed Against Respondents 11

$6 \quad$ Licensee Satisfaction with Mandatory E\&O 12

$7 \quad$ Comments Made by Licensee Survey Respondents 13-17

$8 \quad$ t-test Results: Licensee Satisfaction 22

$9 \quad$ Comments Made by REC Directors 30

10 Mandated E\&O Program Policy Details: November 1, 2004

11 Annual E\&O Claim Information: 2001-2003 37 


\section{Errors \& Omissions Insurance: The Experience of States with Mandatory Programs for Real Estate Licensees}

\section{$\underline{\text { Executive Summary }}$}

Errors and omissions insurance $(\mathrm{E} \& \mathrm{O})$ is a mechanism to transfer financial risk, resulting from honest mistakes or negligence committed by a service provider, from both the service provider and the consumer to an insurance company. Real estate licensees in 38 states are free to obtain this coverage if they so desire, but 12 states currently require their active licensees to have E\&O. The purpose of this study is to present information that policy-makers should consider in deciding whether to implement a mandatory E\&O program in Ohio. Survey data collected from the Real Estate Commission (REC) in the mandated states, 201 REALTORS $^{\circledR}$ operating in those states, survey data collected by the Ohio Association of REALTORS ${ }^{\circledR}$, as well as empirical data collected from RISC, the preeminent mandatory E\&O contract administrator, is presented and analyzed.

Sixty-eight percent of the REALTORS ${ }^{\circledR}$ in E\&O mandated states who responded to the survey indicated that they are "very satisfied" or "satisfied" with mandatory E\&O. This figure is significantly higher than the satisfaction with voluntary E\&O recently reported by Ohio REALTORS ${ }^{\circledR}$. Focusing on licensees in mandated states, significant differences are discovered in satisfaction with mandatory E\&O based on several criteria. Licensees with an E\&O claims history are more satisfied compared to those who have never had a claim. Licensees who stated that they would continue to carry E\&O coverage even if it were not mandatory are more satisfied compared to those who would not. Satisfaction is also significantly positively related to the licensee's tenure in real estate. Perhaps most importantly, licensees who have operated under both a voluntary and a mandatory E\&O system are more satisfied compared to those who have operated 
exclusively under a mandatory system. Three recurring themes appear in the comments made by respondents: an appreciation of the low cost for coverage due to group purchasing power, concern that claim limits are too low, and concern that having E\&O increases the probability that the licensee will be subjected to a frivolous lawsuit.

RECs in mandated states are "very satisfied" with mandatory E\&O. Their motivations for mandating E\&O included the desire to maintain or increase consumer and licensee protection, and to provide licensees with affordable E\&O coverage. Comments made by the RECs and RISC provide insights into administrative issues including some which should be considered when implementing a mandatory program. It is recommended that statutory requirements be kept basic; greater program flexibility is achieved when program details are contained in Rules and Regulations administered by the REC.

If Ohio officials decide to implement a mandatory E\&O program, coverage will not be new to most Ohio licensees. Over $90 \%$ of Ohio REALTORS ${ }^{\circledR}$ already have coverage and REALTORS ${ }^{\circledR}$ constitute approximately $80 \%$ of all Ohio real estate licensees. Although there are some disadvantages associated with mandatory programs, there are also impressive advantages. A rough estimate suggests that under a group program the 2005 policy premium in Ohio would be less than $\$ 300$ per licensee. 


\section{Errors \& Omissions Insurance: The Experience of States with Mandatory Programs for Real Estate Licensees}

\section{Introduction}

Errors and omissions insurance $(\mathrm{E} \& \mathrm{O})$ is the functional equivalent of the professional liability insurance carried by physicians, attorneys, architects, and other professionals. E\&O provides a means to indemnify clients and customers who are financially damaged by an honest mistake or negligent error made by a real estate licensee, which, in turn, protects the licensee because a claim filed against a licensee who does not have E\&O can be both financially and professionally disastrous. Common claims filed against real estate licensees range from failure to negotiate a sale to misrepresentation of a property's physical condition. ${ }^{1}$

Both the affordability and availability of E\&O was affected by the events of September $11^{\text {th }}$ and the subsequent tightening of market conditions. Historically, many insurance companies were able to write $\mathrm{E} \& \mathrm{O}$ policies even if the policies were only marginally profitable. During the 1990's, many insurers were even willing to incur underwriting losses in order to increase market share. They could do so because they generated enough income on their investments to operate profitable. In recent years, however, most insurance companies have not earned high returns on their investments (many lost money). Therefore, companies are now focusing on operating at an underwriting profit.

\footnotetext{
${ }^{1}$ Eighty percent of lawsuits against real estate licensees are brought by buyers, and two thirds of those have to do with the condition of the property according to an article entitled "Cut Your Risk Exposure Now" written by Blanche Evans which is available on the Realty Times web site (www.realtytimes.com). Several other interesting $\mathrm{E} \& \mathrm{O}$ related articles are also available on the site.
} 
In recent years, many insurance companies have stopped writing E\&O or have greatly increased premiums, making it difficult for many licensees to obtain coverage. Some Real Estate Commissioners at the 2003 ARELLO Annual Meeting reported that they could not find an insurance provider willing to quote coverage at any price. Proponents of mandatory $\mathrm{E} \& \mathrm{O}$ assert that a mandated program helps ensure that consumers will be protected if a licensee makes an error or omission in their professional service because all, not just some, licensees have coverage. In addition, based on the comments received from both licensees and regulators in the present study, it is apparent that the availability of a group program in the mandated states helps make E\&O coverage available at affordable rates.

The purpose of the present study is to gather and present information that may be used by policy makers in contemplating a mandatory E\&O program for Ohio, although much of the information should also be of value to regulators in other states. To accomplish this objective, the experience of parties in states with existing mandatory programs is investigated using survey data collected from both the Real Estate Commission (REC) in the mandated states and 201 real estate licensees operating in those states, and empirical data collected from Rice Insurance Services Company (RISC), the preeminent mandatory E\&O contract administrator.

The remainder of the paper is organized in the following fashion. In the next section, a brief review of the 2004 Ohio Association of REALTORS ${ }^{\circledR}$ Member Survey is presented, focusing on questions that addressed errors and omissions insurance. In the third section, the states which have a mandatory E\&O program are identified. Survey data collected from licensees in those states is presented in the fourth section, and 
analyzed in the fifth section. In the sixth section, information obtained from the RECs and RISC is presented. The last section contains information concerning the implementation of a mandatory E\&O program.

\section{OAR Member Survey}

Ohio real estate licensees are not required to have $\mathrm{E} \& \mathrm{O}$, but survey data gathered by the Ohio Association of REALTORS ${ }^{\circledR}$ (Stitz, (2004)) suggests that its members have an appreciation of $\mathrm{E} \& \mathrm{O}$ coverage. In $2004,92 \%$ of the sales associates and $91 \%$ of the brokers reported that they have E\&O. These figures are significantly higher than apply nationwide. According to a 2003 survey conducted by the National Association of REALTORS $^{\circledR}, 83 \%$ of all agents and $73 \%$ of all brokers had E\&O. ${ }^{2}$

Of the (approximately) $8 \%$ of OAR survey respondents who indicated that they did not have $\mathrm{E} \& \mathrm{O}, 37.4 \%$ ( $3 \%$ of all respondents: i.e., $8 \%$ x .374) reported that the reason for lack of coverage was that it was too expensive, $23.1 \%$ (1.8\% of all respondents) stated that they did not believe it was necessary, $16 \%$ (1.3\% of all respondents) indicated that they intended to obtain coverage but had not yet done so, and $5.5 \%(0.4 \%$ of all respondents) stated that they cannot obtain coverage due to previous claims.

Of the (approximately) $92 \%$ of OAR survey respondents that have $\mathrm{E} \& \mathrm{O}, 45 \%$ of the agents indicated that they paid for the coverage themselves, $25.2 \%$ reported that their broker paid the premium, and $29.9 \%$ reported that the cost was shared between them and

\footnotetext{
${ }^{2}$ These lower national percentages do not provide a perfect comparison to Ohio because they overstate the percentage of REALTORS ${ }^{\circledR}$ in other states who have voluntarily obtained E\&O; they include REALTORS ${ }^{\circledR}$ in both Ohio and in twelve states where coverage is mandatory.
} 
their broker. At their most recent policy renewal, $43 \%$ of the respondents reported that the premium on their E\&O policy increased. The average increase was $20 \%$.

Less than half of the OAR survey respondents with E\&O stated that they were "satisfied" or "extremely satisfied" (on a five point Likert scale) with various aspects of the coverage. Only $35.5 \%$ expressed satisfaction regarding the cost of coverage; $43.6 \%$ expressed satisfaction with the adequacy of the coverage; $40.4 \%$ expressed satisfaction with claims handling/administration; and $42.5 \%$ expressed satisfaction with the customer service provided by the insurance provider. Given the above data it is not surprising that of the seventeen issues enumerated in the OAR survey, "errors and omissions insurance" was ranked by respondents as the eighth most important challenge that Ohio REALTORS $^{\circledR}$ will face in the near future. ${ }^{3}$ Seventy percent of respondents indicated this issue was either "important" or "very important" on a five-point Likert scale.

It is worth emphasizing that if Ohio officials decide to make E\&O mandatory, coverage will not be new to most Ohio real estate licensees. As mentioned above, over $90 \%$ of Ohio's REALTORS ${ }^{\circledR}$ already have E\&O, and REALTORS ${ }^{\circledR}$ constitute about $80 \%$ of Ohio's 39,642 real estate licensees. In addition, the lower E\&O premium usually available through a group program (discussed later in this paper) may be attractive to licensees who already have E\&O but are not satisfied with the cost of coverage, as well as the $3 \%$ who claim the reason they are not currently covered is due to high premiums. Mandatory E\&O would also likely be motivational for the $1.3 \%$ of licensees who are

\footnotetext{
3 The other issues listed in the OAR survey include: bottom line profit of brokerage, personal earnings, fluctuations in the economy, changing demographics that affect the marketplace, REALTOR ${ }^{\circledR}$ image, attracting new sales agents, FSBOs, expanding beyond traditional brokerage services, the growing importance of the Internet, keeping up with computer skills, licensure law compliance, do not call registry, RESPA reform, mold inspections, availability of residential and commercial property insurance, and retaining sales agents. Concerning the last and next to last issues, interested readers may want to see Larsen and Coleman (2003), and Coleman and Larsen (2004), respectively.
} 
procrastinating in obtaining coverage, good news for the $0.4 \%$ who assert that they are uninsurable, and resisted by the $1.8 \%$ who believe $\mathrm{E} \& \mathrm{O}$ is unnecessary. ${ }^{4}$

\section{States with Mandatory E\&O Programs}

Twelve states currently require their active real estate licensees to have E\&O. These states, shown in Exhibit 1, include: Colorado, Idaho, Iowa, Kentucky, Louisiana, Mississippi, Nebraska, New Mexico, North Dakota, South Dakota, Tennessee, and (although, due to its size, it does not show well in Exhibit 1) Rhode Island. ${ }^{5}$ Ohio has reciprocity agreements with four of these states: Colorado, Kentucky, Nebraska, and Mississippi. ${ }^{6}$

\section{Exhibit 1}

\section{$\underline{\text { Location of States with Mandatory E\&O }}$}

- States with E\&O Ins.
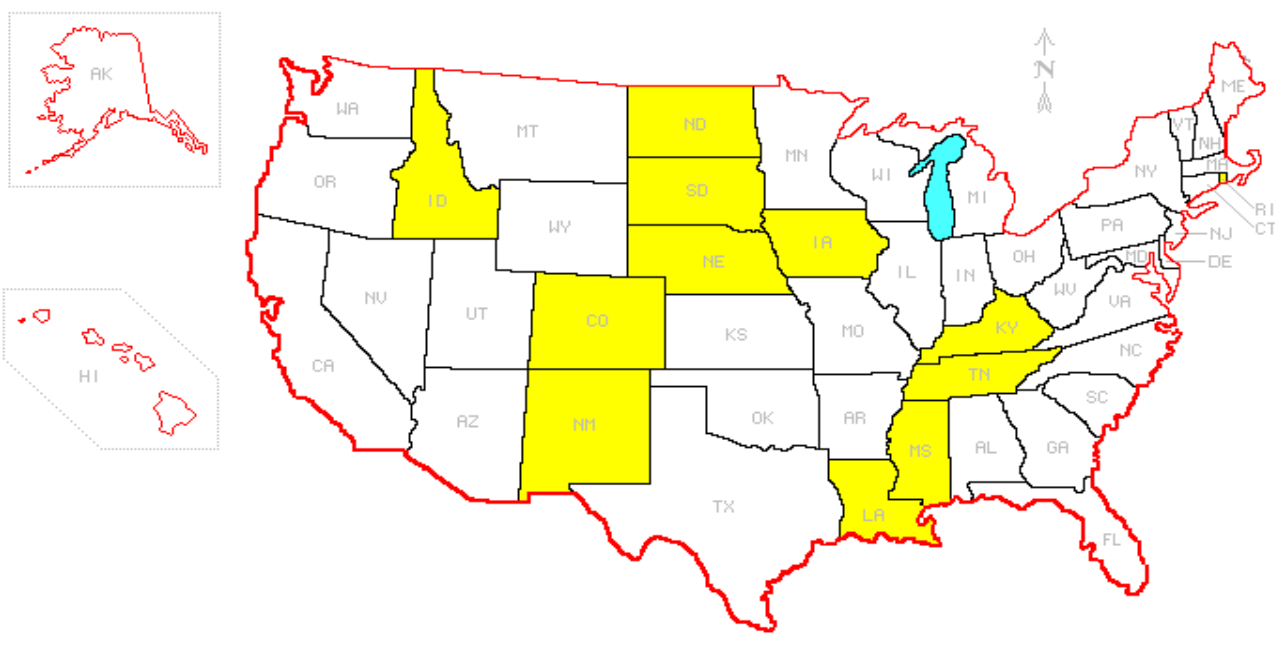

\footnotetext{
${ }^{4}$ A state-sponsored program must offer the policy to every licensee at the same price, with no right on the part of the insurance provider to cancel an individual licensee. This is true, even if a licensee has a lot of previous claims and cannot obtain coverage on their own outside of the group program.

${ }_{5}^{5}$ Alabama formerly had mandatory E\&O, but repealed the requirement on April 25, 2003.
} 
Examination of Exhibit 2 will reveal that Kentucky, in 1987, was the first to implement a mandatory E\&O program, and that New Mexico and North Dakota, in 2002, are the most recent states to do so. All of the states with mandatory programs are smaller than Ohio based on at least two criteria. The estimated 2004 population of Ohio is 11,435,798 and as of October, 2004 there were 39,642 real estate licensees in Ohio.

\begin{tabular}{|lccc|}
\hline \multicolumn{4}{c|}{ Exhibit 2 } \\
& \multicolumn{3}{c}{ Twelve States with Mandatory E\&O } \\
State & $\begin{array}{c}\text { E\&O } \\
\text { Mandatory } \\
\text { Since }\end{array}$ & $\begin{array}{c}\text { Active Licensees } \\
\text { Colorado }\end{array}$ & $\begin{array}{c}\text { 2004 Estimated } \\
\text { State Population }\end{array}$ \\
Idaho & $1-1-1998$ & 31,963 & $4,550,688$ \\
Iowa & $12-31-1993$ & 6,005 & $1,366,332$ \\
Kentucky & $7-1-1991$ & 7,899 & $2,944,062$ \\
Louisiana & $4-1-1987$ & 24,848 & $4,117,827$ \\
Mississippi & $1-1-1990$ & 14,324 & $4,496,334$ \\
Nebraska & $7-1-1994$ & 8,005 & $2,881,281$ \\
New Mexico & $1-1-1993$ & 7,363 & $1,739,291$ \\
North Dakota & $1-1-2002$ & $9,650 *$ & $1,874,614$ \\
Rhode Island & $1-1-2002$ & 1,750 & 633,837 \\
South Dakota & $7-12-1990$ & 6,223 & $1,076,164$ \\
Tennessee & $8-16-1993$ & 2,649 & 764,309 \\
* total licensees: the New Mexico REC licensing staff member did not know the \\
number of inactive licensees.
\end{tabular}

${ }^{6}$ The implications of reciprocity and mandatory E\&O are addressed in section 6.6. 


\section{The Licensees Perspective}

A survey was delivered via email to 1,069 REALTORS $^{\circledR}$ licensed in one of the twelve states which require them to carry E\&O. ${ }^{7}$ The licensees to whom the survey was emailed were selected using a "find a REALTOR ${ }^{\circledR}$ " search engine available on the National Association of REALTORS ${ }^{\circledR}$ web site. ${ }^{8}$ To be eligible to receive the survey, it was required that the licensee have an individual (rather than a company) email address. The results should be viewed with some caution because of the relatively small sample size and because we are uncertain what bias, if any, the data source and/or the "individual email address" requirement introduces. The results are interesting none the less.

Two hundred one usable responses were received; an overall response rate of $18.8 \%{ }^{9}$ In an attempt to enhance the response rate, the survey was kept brief (eight questions). The only demographic information collected on the survey was the number of years the respondent had worked in real estate. In addition, we were able to identify respondent gender from a variety of internet sources. ${ }^{10}$ Approximately 48\% (96/201) of the respondents were female and 52\% (105/201) were male. Examination of the data in Exhibit 3, where respondent tenure in real estate is detailed, reveals that, as a group, the

\footnotetext{
${ }^{7}$ The survey may be viewed in full at www.wright.edu/ joseph.coleman. 1,200 emails were sent, but for reasons unknown (we suspect a combination of turnover in the brokerage industry and the foibles of the internet) only 1,069 emails were successfully delivered. The overall and state response rates (shown in footnote 9) are based on the number of emails successfully delivered.

${ }^{8}$ realtor.org/rodesign.nsf/pages/ RealtorDirectory?OpenDocument.

${ }^{9}$ Response numbers (rates) for individual states were: Colorado -9 of 83 (10.8\%), Idaho - 26 of 93 (28.0\%), Iowa -6 of 81 (7.4\%), Kentucky - 12 of 84 (14.3\%), Louisiana 11 of 100 (11.0\%), Mississippi 20 of $92(21.7 \%)$, Nebraska - 7 of 98 (7.1\%), New Mexico - 19 of $90(21.1 \%)$, North Dakota -23 of 89 (25.8\%), Rhode Island - 21 of 89 (23.6\%), South Dakota - 21 of 79 (26.6\%), and Tennessee - 26 of 91 $(28.6 \%)$.

${ }^{10}$ For most people we were able to determine gender from the NAR site. For three dozen with names like Chris and Terry, gender was determined by visiting their state association of REALTORS ${ }^{\circledR}$, firm, or personal web site.
} 
survey respondents have substantial real estate experience; their average tenure in real estate was 16.4 years. ${ }^{11}$

\begin{tabular}{|lccccc|}
\hline \multicolumn{5}{c}{ Exhibit 3 } \\
& \multicolumn{5}{c}{ Licensee Years in Real Estate } \\
State & $\underline{n}$ & $\underline{\text { Mean }}$ & $\underline{\text { High }}$ & Standard \\
Deviation \\
Colorado & 9 & 19.8 & 7 & 35 & 9.9 \\
Idaho & 26 & 12.5 & 1 & 30 & 9.3 \\
Iowa & 6 & 17.8 & 8 & 35 & 10.3 \\
Kentucky & 12 & 17.3 & 6 & 35 & 10.2 \\
Louisiana & 11 & 17.3 & 6 & 33 & 9.9 \\
Mississippi & 20 & 18.3 & 6 & 32 & 9.5 \\
Nebraska & 7 & 22.3 & 7 & 42 & 12.6 \\
New Mexico & 19 & 15.3 & 3 & 33 & 11.2 \\
North Dakota & 23 & 15.3 & 1 & 34 & 10.1 \\
Rhode Island & 21 & 13.9 & 1 & 33 & 10.3 \\
South Dakota & 21 & 17.6 & 1 & 35 & 11.0 \\
Tennessee & 26 & 18.5 & 9 & 30 & 8.0 \\
Total & 201 & 16.4 & 1 & 42 & 10.0 \\
\hline
\end{tabular}

The licensee survey contained (among others) the following three questions:

- Did you obtain your current E\&O policy through your state-sponsored program?

- If E\&O insurance was not mandatory and you could continue to obtain it at the same premium you are currently paying, would you continue to be covered?

${ }^{11}$ According to NAR (2003), in 2003, 52\% of all REALTORS ${ }^{\circledR}$ are female, and the typical NAR member 
- Who pays your E\&O premium (with the following choices: You, Your broker, and Shared by you and your broker)?

Examination of the second and third columns in Exhibit 4 will reveal that $72 \%$ (144/200) of respondents obtained their E\&O coverage through their state sponsored provider and $28 \%(56 / 200)$ obtained their coverage independently. ${ }^{12}$ In the shaded portion of Exhibit 4, details are presented of the $92.4 \%(182 / 197)$ of respondents who indicated that they would continue to carry insurance (at the current premium) even if it were not mandatory and the $7.6 \%(15 / 197)$ who indicated that they would not. In the last three columns of Exhibit 4, it is shown that $83.1 \%(167 / 201)$ of the respondents indicated that they pay for their E\&O coverage. However, 11.4\% (23/201) reported that their broker paid the premium and 5.5\% (11/201) indicated that the cost was shared between them and their broker. ${ }^{13}$

Survey participants were also asked, "How many claims have been filed against your E\&O policy? Examination of Exhibit 5 will reveal that $85.1 \%(171 / 201)$ of the respondents indicated that they had never had an E\&O claim filed against them. However, 14.9\% (30/201) indicated that one or more claims had been filed against them. Given information presented elsewhere in this paper concerning the total number of claims (section 6.6) and licensees in each state (section 3), it is not surprising that the

\footnotetext{
had 13 years experience in real estate.

${ }^{12}$ As of October, 2004, the average participation rate in state sponsored plans for all active licensees in all 12 states is $71.7 \%$. The participation rate for all active licensees in each state as of the same date are: Colorado $-65.8 \%$, Idaho $-89.7 \%$, Iowa $-98.7 \%$, Kentucky $-51.6 \%$, Louisiana $-95.4 \%$, Mississippi $70.0 \%$, Nebraska $-83.5 \%$, New Mexico $-65.3 \%$, North Dakota $-46.6 \%$, Rhode Island $-41.4 \%$, South Dakota $-67.8 \%$, and Tennessee $-83.5 \%$.

${ }^{13}$ Premium cost sharing is not applicable in Colorado which has a single-class licensee system. Regardless, a substantially larger percentage of REALTORS ${ }^{\circledR}$ in the mandatory E\&O states pay their own E\&O premium compared to Ohio REALTORS ${ }^{\mathbb{B}}$.
} 
majority of the respondents have not been involved in a claim. On the other hand, the latter group may be overrepresented in our sample. The benefit of this is that it facilitates a subsequent comparison of the two groups.

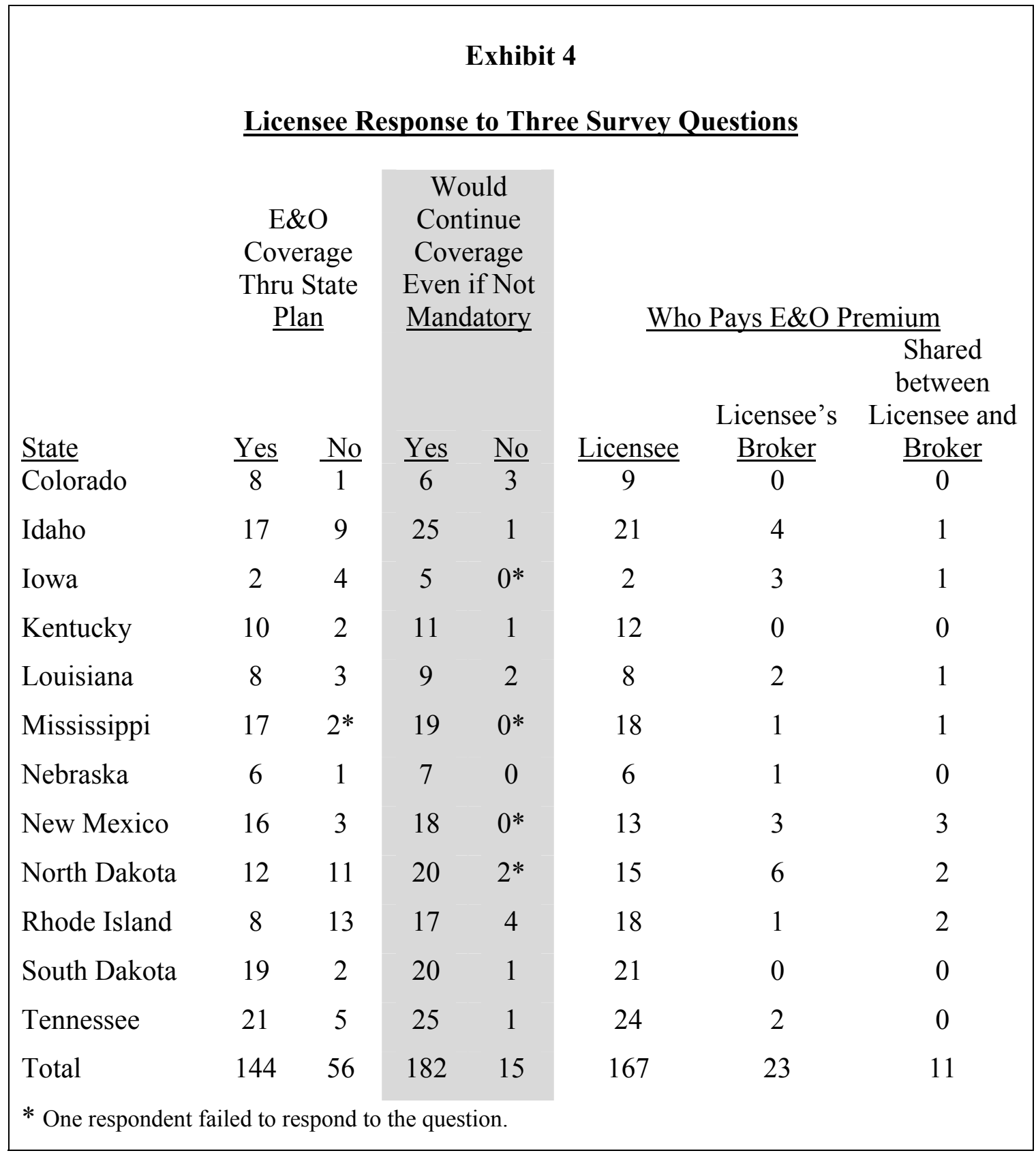




\begin{tabular}{|lccccc|}
\hline \multicolumn{5}{c|}{ Exhibit 5 } \\
\multicolumn{7}{|c}{ Number of E\&O Claims Filed Against Respondents } \\
State & Zero & One & $\underline{\text { Two }}$ & $\underline{\text { Three }}$ & $\underline{\text { Five }}$ \\
Colorado & 8 & 1 & 0 & 0 & 0 \\
Idaho & 23 & 1 & 1 & 1 & 0 \\
Iowa & 5 & 1 & 0 & 0 & 0 \\
Kentucky & 11 & 1 & 0 & 0 & 0 \\
Louisiana & 9 & 1 & 0 & 0 & 1 \\
Mississippi & 15 & 5 & 0 & 0 & 0 \\
Nebraska & 6 & 0 & 1 & 0 & 0 \\
New Mexico & 16 & 3 & 0 & 0 & 0 \\
North Dakota & 19 & 4 & 0 & 0 & 0 \\
Rhode Island & 18 & 3 & 0 & 0 & 0 \\
South Dakota & 18 & 3 & 0 & 0 & 0 \\
Tennessee & 23 & 3 & 0 & 0 & 0 \\
Total & 171 & 26 & 2 & 1 & 1 \\
\hline
\end{tabular}

Licensees were asked to respond to the following question, "How satisfied are you with your experience with mandatory E\&O insurance coverage?" Possible responses included: very satisfied, satisfied, neutral, dissatisfied, and very dissatisfied. Examination of Exhibit 6, where the results are detailed, reveals that the mandatory programs have been fairly well received by respondents. Twenty-three and a half percent (47/200) reported being very satisfied, $44.5 \%$ (89/200) were satisfied, $29 \%(58 / 200)$ were neutral, and 3.0\% (6/200) were dissatisfied. None indicated that they were very 
dissatisfied. Note that $68 \%$ of the respondents were at least satisfied. This figure is significantly higher than any of the E\&O satisfaction levels reported in the 2004 OAR Member Survey.

\begin{tabular}{|c|c|c|c|c|c|c|}
\hline \multicolumn{7}{|c|}{$\begin{array}{c}\text { Exhibit } 6 \\
\text { Licensee Satisfaction with Mandatory E\&O }\end{array}$} \\
\hline State & $\begin{array}{c}\text { Very } \\
\text { Satisfied }\end{array}$ & Satisfied & $\underline{\text { Neutral }}$ & Dissatisfied & $\begin{array}{c}\text { Very } \\
\text { Dissatisfied }\end{array}$ & Total \\
\hline$\overline{\text { Colorado }}$ & 2 & 5 & 1 & 1 & 0 & 9 \\
\hline Idaho & 2 & 11 & 12 & 1 & 0 & 26 \\
\hline Iowa & 0 & 5 & 1 & 0 & 0 & 6 \\
\hline Kentucky & 7 & 2 & 3 & 0 & 0 & 12 \\
\hline Louisiana & 4 & 3 & 3 & 1 & 0 & 11 \\
\hline Mississippi & 5 & 10 & 5 & 0 & 0 & 20 \\
\hline Nebraska & 2 & 4 & 1 & 0 & 0 & 7 \\
\hline New Mexico & 4 & 7 & 6 & 1 & 0 & $18^{*}$ \\
\hline North Dakota & 5 & 14 & 4 & 0 & 0 & 23 \\
\hline Rhode Island & 4 & 7 & 8 & 2 & 0 & 21 \\
\hline South Dakota & 5 & 8 & 8 & 0 & 0 & 21 \\
\hline Tennessee & 7 & 13 & 6 & 0 & 0 & 26 \\
\hline Total & 47 & 89 & 58 & 6 & 0 & 200 \\
\hline
\end{tabular}

Finally, the survey gave participants the opportunity to make any comments that they wished about E\&O insurance; 41 individuals, from 9 states, elected to do so. Examination of their comments, presented in the second column of Exhibit 7, is instructive. Close reading of the comments will reveal approximately the same number of favorable and unfavorable comments. Three recurring themes appear in the 
comments: an appreciation of the low cost for coverage due to group purchasing power, concern that claim limits are too low, and concern that having E\&O coverage increases the probability that the licensee will be subjected to a frivolous lawsuit (although the latter would apply whether or not coverage was mandatory). ${ }^{14}$ Information in the first column of Exhibit 7 includes the state in which the respondent was licensed and the respondent's reported satisfaction level.

\section{Exhibit 7}

\section{Comments made by Licensee Survey Respondents}

\section{State}

Satisfaction

level

$\underline{\text { Comments }}$

Idaho

Very satisfied

I support mandatory E\&O because many licensees do not carry it

Satisfied otherwise and it leaves an unfair playing field.

This has caused more paperwork.

Satisfied

I would continue to carry it if it was not mandatory, but it would be much higher if I paid on my own. The state program is the best $\$ \$$ but not nearly enough coverage today.

Satisfied If one does ethically sound business, and always watches out for the best interests of his or her clients, you should never have to have E\&O Insurance.

Satisfied Our state policy is not very much, $\$ 100 \mathrm{k}$. Everyone in our brokerage gets additional coverage that takes us up to $\$ 1$ million. I believe that is the amount. My broker requires this, so it is really up to him, but I think it is a good thing to do.

\footnotetext{
${ }^{14}$ Our study includes some anecdotal evidence which is not inconsistent with this concern. Of the states that had a recovery fund at the time $\mathrm{E} \& \mathrm{O}$ was mandated, the RECs unanimous response was that there was no significant difference in the number of recovery fund claims in the years before and after E\&O was mandated. However, we do not have access to the number of independently-obtained $\mathrm{E} \& \mathrm{O}$ claims in the years surrounding the mandatory $\mathrm{E} \& \mathrm{O}$ implementation dates. On a separate issue addressing licensee concern about low claim limits: licensees are able to purchase additional coverage for an added premium.
} 


\section{Exhibit 7 continued}

Idaho

Satisfied

Neutral

Dissatisfied

Kentucky

Very satisfied

Very satisfied

I

I tried to obtain insurance when I was first in the business, before it was mandatory, and found it to be cost prohibitive. Fortunately, I have not had to file any claims. Some of the agents in my office had complaints, we chose not to file a claim, but settled these minor complaints. I was in the real estate business before our mandatory insurance and after. I applaud the state of KY for being pro-active to mandate this insurance. It helps the licensee and also safeguards the public. It is money well spent each year. In my experience, the only down-side I have found is comments I have heard attorneys make to their clients. It has been suggested by attorneys that a client sue their agent, "because, after all, they have insurance to cover them."

Very satisfied The policy has been very good for agents and brokers in Kentucky. Since Kentucky was the first state in the nation to have a mandatory policy for E\&O others have followed. While the coverage is small the ability to purchase additional coverage at affordable rates is great. This has been a great service offered by the Real Estate Commission.

Neutral

Fortunately, I have never used my E\&O Insurance. However, I do feel that the policy offers very little coverage for me. I pay it to keep in line with what is required of me with the Real Estate Commission, and for what little coverage it gives me. I wish we had more choices. 


\section{Exhibit 7 continued}

Mississippi I wish the insurance company would fight more claims. (Researchers Very satisfied note: the information in section 6.7 shows the insurance provider successfully contests many claims)

Very satisfied Of course the major problem with mandatory E\&O Insurance is that all trial lawyers now know that licensees are required to carry it, therefore the very product that protects us from claims also makes us more of a target.

Very satisfied If we did not have mandatory insurance some of the brokers would not carry it. They think of it as unnecessary.

Satisfied I formerly had coverage through state-sponsored E\&O and there was a claim filed that was thrown out of court. The E\&O company would not go back to court with us to ask for reimbursement of all fees in conjunction with the case. We went back for the deductible and court costs, etc. but the judge would have awarded us all attorneys fees paid by the insurance company had they been a party to the suit. We felt that would have sent a strong message to the attorney who is notorious for filing frivolous suits against realtors. They paid money for attorneys, etc. that could have been reimbursed.

Satisfied I would like for our coverage to be higher. The deductible is reasonable but the coverage amount is small considering how expensive homes are getting to be. The price of our coverage seems to be very low because of the group buying power. I wish we had an option to go higher on the coverage and still get the group buying power price.

Satisfied I am strongly against fraudulent law suits. I do not think my E\&O insurance is too expensive but I do think the likelihood of being sued for a fraudulent reason and LOSING is way too high. I am from Mississippi which has the worst record for these types of claims and I am angry about it.

Neutral If my umbrella policy would not cover me, I probably would continue to buy E\&O coverage if it were not mandatory.

Neutral I consider E\&O insurance a necessary evil. It is a shame that in today's world we must insure ourselves against practically everything.

Nebraska I believe that mandatory E\&O insurance is a way to lower the cost of Very satisfied purchasing the coverage. We are very pleased to have all licensees covered. 


\section{Exhibit 7 continued}

Nebraska

Satisfied

New Mexico

Satisfied

Dissatisfied

Dissatisfied

North Dakota Satisfied

Satisfied

Satisfied

\section{Rhode Island} Very satisfied

Satisfied

Satisfied

Neutral
I have been very fortunate and never had to file a claim, but as the years go by, it seems very important to have it every year.

It would be nice to know it is with consistent carriers instead of being put out to bid often.

The mandatory E\&O is a joke. The limits are less than we were carrying and the additional coverage offered still does not satisfy what we did have.

Our state E\&O policy does not insure over fraud or intentional acts to mislead, deceive, etc.

Our company carried E\&O before it was mandatory, so most of these questions do not apply to us.

It appears from years of experience and from one personal court case that the consumer (i.e. plaintiff) considers the pockets of insurance companies much deeper than that of any individual Realtor and they will quickly act to sue or co-join anyone with that "asset".

We carried other coverage previous to the mandatory coverage, but they kept raising the premiums and reducing the coverage, so it made sense to go with the group plan even though the coverage was substantially less.

One claim in 26 years is being dismissed.

I feel that having E\&O insurance helps protect me against new, untrained agents who do not know what they are doing and put all of us at risk in this litigious society.

Many E\&O policies do not cover past transactions. Many agents, especially those who change brokers do not realize that they probably are not covered if one of those previous transactions has a problem down the road and their old policy doesn't cover them because they are no longer with that Broker and their new policy doesn't cover it either. I've taken out my own policy for business insurance to cover my business, my business property and to give me additional coverage that would also cover my deductible if I am ever sued and lose.

Why is it so expensive? I think I pay $\$ 350$ per year and that is after taking a risk management class to reduce the price. 


\section{Exhibit 7 continued}

South Dakota There is so much potential liability in this business and we live in such a

Satisfied litigiousness society. I would certainly never be without it.

Satisfied Our state sponsored E \& O Insurance does not have high enough limits to satisfy our Franchise requirements, therefore we needed to obtain our E\&O Insurance from an outside carrier.

Neutral The insurance is a target of customers and their attorneys who are making frivolous claims and the Realtor's involved have no say when the companies settle instead of fighting a claim. It is less expensive to pay insurance they say, but it only encourages more lawsuits.

Neutral We get $\$ 500,000$ through the state program and $\$ 500,000$ through a private carrier.

Tennessee I like the fact that our state requires E\&O. I wish the maximum was Very satisfied increased from $\$ 100 \mathrm{~K}$ to at least $\$ 500 \mathrm{k}$ or even $\$ 1 \mathrm{M}$. Our current minimum is too low and with group rates the increased premiums should not be excessive.

Very satisfied I am actually looking into less expensive comprehensive insurance for both the agents and the firm for the next premium period. I feel that agents and firms with long histories of NO claims should have less expensive policies!

Very satisfied I had E\&O coverage long before it was mandatory, and long before other area brokers chose to do so. Most did not have coverage until it was mandatory. I cannot imagine being in this business without the coverage.

Satisfied Our company negotiates coverage for all our sales associates. I personally have had no claims, but there have been claims against our "company" policy. E\&O Insurance has always been one of those expenses that are "a given"...a cost associated with doing business, you've raised some interesting questions.

Satisfied I had one claim but no payment was made to the complainant as the charge was determined to be untrue.

Neutral Currently our premium is $\$ 260.00$ for low coverage. 


\section{Analysis of Licensee Survey Data}

In this section, the results of tests conducted to determine if several variables are significantly related to licensee satisfaction with mandatory E\&O are reported. Two preliminary tests were conducted. One, to investigate whether state survey response rates are related to average respondent satisfaction levels within the state. It would be problematic if these variables are significantly related, however, a Pearson correlation test indicates that they are not. The Pearson correlation coefficient (r) is .338 with a $p$ value of .28. In addition, the results of an ANOVA indicate no significant difference in average satisfaction levels by state ( $\mathrm{p}$ value $=.21$ ). These results allow us to conduct the following tests on all respondents as a single group.

A t-test was used to determine if satisfaction levels differ significantly between: 1) licensees who pay for their own coverage and those whose broker pays, or shares, the premium cost, 2) licensees who have, and have not, experienced an E\&O claim, 3) licensees who obtained $\mathrm{E} \& \mathrm{O}$ coverage through the state sponsored provider and those who obtained coverage independently, 4) licensees who would continue to carry E\&O coverage even if it were not mandatory and those who would not, 5) licensees who have operated under both a voluntary and a mandatory system and those who have only operated under a mandatory program, 6) licensees located in one of the eight mandatory E\&O states with a real estate recovery fund and those located in one of the four mandatory E\&O states without a recovery fund, and also whether satisfaction levels differ by 7) licensee gender

- To address these issues, the mean satisfaction level for the two groups in each of the above seven cases was calculated. The mean value was obtained by assigning a 
numerical value to each respondent's reported satisfaction level: 1 for very satisfied, 2 for satisfied, 3 for neutral, and 4 for dissatisfied (i.e., the lower the mean value, the higher the satisfaction level). Then a two-tailed t-test was applied. The results of all t-tests are described in the following paragraphs and summarized in Exhibit 8. Finally, both a onefactor ANOVA and a Tukey Kramer multiple comparison test were employed to test whether licensee tenure in real estate is significantly related to licensee satisfaction with mandatory E\&O.

A priori, it seems logical that not being responsible for the premium payment might result in greater satisfaction with a mandatory system. But, the t-test results indicate no significant difference between the 166 licensees that pay their own coverage and the 34 who pay only some, or none, of the premium.

It also seems logical, a priori, that a person who has gone through the claims process might be more favorably inclined toward a mandatory system (although this would depend upon how effectively the claim was handled) because the licensee has first-hand knowledge of the financial protection E\&O provides. A licensee who has never had a claim filed against them may, not necessarily correctly, view E\&O insurance in general as unneeded, and, therefore, consider a mandatory system as a vehicle that forces them to carry the "unneeded" coverage. The t-test results indicate that the 30 licensees with a claims history are more satisfied with mandatory E\&O compared to the 170 with no claims history. The difference between the mean values of the two groups is significant at the $5 \%$ confidence level.

It is plausible, although not necessarily probable, that a licensee who opposes a mandated program, would signal his/her dissatisfaction by refusing to obtain coverage 
with the state sponsored carrier. The t-test results, however, indicate no significant difference in satisfaction levels between 143 licensees who obtained coverage through their state plan and the 57 who obtained coverage independently.

It is intuitive that a licensee who indicated that he/she would not carry E\&O if it were not required is unlikely to be satisfied with a program that mandates coverage. Not surprisingly, the t-test results indicate that the satisfaction level of 181 licensees who stated that they would continue coverage is significantly higher than the 19 who stated that they would not. The difference in the mean values of the two groups is significant at the $1 \%$ confidence level.

A priori, it is plausible that licensees who have operated under both a voluntary and mandatory system may be in a better position to appreciate the reduced premiums that have been achieved with group purchasing power and, therefore, be more satisfied with mandatory E\&O compared to licensees who have only operated under a mandatory system. Licensees in our sample were divided into these two groups by comparing the licensee's tenure in real estate to the number of years that $\mathrm{E} \& \mathrm{O}$ had been mandatory in the state in which the licensee operates. The t-test results indicate that the 137 licensees who have worked under both a voluntary and mandatory E\&O system are more satisfied with mandatory $\mathrm{E} \& \mathrm{O}$ compared to the 63 who had worked only under a mandatory system. The difference in the mean satisfaction level of the two groups is significant at the $1 \%$ confidence level.

There is little reason to suggest that satisfaction levels should differ by licensee gender, but the gender issue is examined here because other real estate studies have 
identified differences based upon this criteria. ${ }^{15}$ The t-test results indicate indicates no significant difference in satisfaction levels between the 96 females and the 104 males in our sample.

Only eight of the mandatory E\&O states also have a real estate recovery fund, including: Colorado, Idaho, Kentucky, Louisiana, North Dakota, Rhode Island, South Dakota and Tennessee. Recovery funds, normally funded by fees levied on licensees, may provide consumers with additional protection because the funds can be used to indemnify consumers that have been financially damaged in a transaction that is excluded by the E\&O policy or a claim that exceeds the E\&O claim limit. Despite this, it is possible that licensees in the eight states with a recovery fund view the two programs as redundant, and, therefore, hold $\mathrm{E} \& \mathrm{O}$ in lower regard. The t-test results, however, indicate no difference in mean satisfaction between the 148 licensees located in one of the eight states with a recovery fund and the 52 located in one of the four states without a recovery fund.

A priori, it is plausible that the more experience a licensee gains the more he/she realizes the importance of $\mathrm{E} \& \mathrm{O}$ and, therefore, the more likely the licensee is to be satisfied with mandatory E\&O. The ANOVA results indicate a significant relationship between the number of years experience possessed by a licensee and satisfaction with mandatory E\&O $(\mathrm{p}<.0001)$. In addition, the results of a Tukey Kramer multiple comparison test indicates that the mean number of years in business for the 47 respondents who were "very satisfied" (21.5 years) was significantly higher than both the

\footnotetext{
${ }^{15}$ Difference in male and female disclosure (of psychological stigma) behavior is documented in Larsen and Coleman (2001), and gender-based differences in income have been found in: Abelson, Kacmar and Jackofsky (1990), Crellin, Frew and Jud (1988), Glower and Hendershott (1988), Sirmans, and Swicegood (1997, 2000).
} 
mean number of years in business for the 89 that were "satisfied" (16.2 years) and the 58 that were "neutral" (12.2 years). There was no significant difference in the mean values between the "very satisfied respondents and the 6 respondents who were "dissatisfied" (20.5 years). All other multiple comparisons were not significantly different.

\begin{tabular}{|c|l|c|c|c|c|c|}
\hline \multicolumn{6}{|c|}{ Exhibit 8 } \\
\multicolumn{7}{|c|}{ t-test Results: Licensee Satisfaction } \\
Group \\
\hline
\end{tabular}




\section{The Regulators Perspective}

This section contains information gathered by survey from the REC in nine of the twelve states with mandatory E\&O. ${ }^{16}$ For expository expedience the information has been divided into six groups. First, the motivations behind the implementation of mandatory E\&O are discussed. Next, REC satisfaction level with mandatory E\&O is presented. Third, the advantages and disadvantages of mandatory programs are presented. Fourth, several mandatory E\&O program administrative issues are presented. Fifth, some of the details of the group policies available under mandatory programs and related regulations are examined. Finally, data on the recent claims history of the group policies for each state is presented.

6.1. Motivations for Mandatory E\&O - REC survey participants were asked to enumerate the motivations for instituting mandatory E\&O in their state. Seven of the nine respondents specifically mentioned the need to maintain or increase consumer protection, three mentioned the need to provide affordable insurance coverage to licensees, and three mentioned the need to maintain or increase licensee protection. In at least one case, the actions of state legislators provided added incentive for real estate officials to recommend mandatory E\&O. In Colorado, the REC was concerned about (then) recently-passed legislation that empowered the state to transfer money from funds such as the real estate recovery fund into the general fund. Such a transfer did, in fact, occur in 2003, dropping the balance in the Colorado recovery fund well below the

\footnotetext{
${ }^{16}$ All twelve REC Directors contacted by phone and asked if they would participate in a written survey agreed to do so. The survey and cover letter were then emailed to each Director. Nine responses were eventually received. Subsequently, the nine participating Directors were contacted by phone to gather some clarifying information. A copy of the survey may be viewed at www.wright.edu/ joseph.coleman.
} 
statutory minimum. This episode may give real estate officials in Ohio pause for concern as there is nothing in the Ohio statutes to prevent similar raiding here. ${ }^{17}$

In most states, regulators initiated the investigation of mandatory E\&O. For example, the Nebraska REC (which had no real estate recovery fund before (or after) mandating $\mathrm{E} \& \mathrm{O}$ ) wanted to provide real estate consumers with some financial protection and was considering establishing a recovery fund. During its investigation the Nebraska regulators learned of the Kentucky E\&O program, decided an E\&O program would require less administrative time, and developed enabling legislation which was enacted into law. In Iowa, however, the move to mandatory E\&O was initiated by the state Association of REALTORS ${ }^{\circledR}$. According to the Iowa REC, before E\&O was mandated, "coverage was difficult to obtain and the premiums were staggering. Premiums would go up, or the policy would be cancelled without claims or cause leaving the licensee without coverage."

As previously mentioned, eight of the twelve states with mandatory E\&O also have a real estate recovery fund. In the researcher's opinion, consumers are best protected by a combination of E\&O and a recovery fund; with the recovery fund being used to settle legitimate claims that exceed the E\&O claim limit or for transactions that are excluded in the E\&O policy (see section 6.6).

6.2. Satisfaction with Mandatory E\&O - Real estate regulators in states which currently mandate E\&O are almost unanimous in their opinion of mandatory E\&O. Eight

\footnotetext{
${ }^{17}$ Similar legislation was passed in Rhode Island and Tennessee after E\&O was made mandatory. In Idaho, the legislature attempted, and failed, to pass such legislation. About $\$ 1,000,000$ has been transferred from the Kentucky real estate recovery fund to the general fund in the in the last two years without the benefit of enabling legislation.
} 
of the nine respondents reported that they were "very satisfied" with mandatory E\&O and one reported being "neutral" (on a five-point Likert scale with possible responses: very satisfied, satisfied, neutral, dissatisfied, and very dissatisfied). The results of a two-tailed t-test ( $\mathrm{p}$ value $>.0001$ ) verify that the regulator's mean satisfaction level is significantly higher than the licensee's mean satisfaction level (section 4). Such a high satisfaction level clearly indicates that regulators believe that the mandatory program has achieved the desired results (section 6.1). The near consensus response, however, prevents statistical analysis of differences in satisfaction levels for RECs as was done for licensees.

Historically, at least one state was unsatisfied with mandatory E\&O. In 2003, Alabama was the first state to repeal its mandatory E\&O requirement. The issue surfaced in 2002 when the Alabama REC conducted a review of their E\&O group program and found that it had been four years since an insurance carrier had been under contract for the state program. Alabama's law required that if the REC was unable to obtain E\&O to insure all licensees who choose to participate in the program, the requirement of insurance coverage was void during the applicable contract period. In essence, the statutory language did not permit Alabama to require insurance when the REC could not make a group policy available and the insurance provider concluded that the loss experience in Alabama did not support a decision to continue to offer a program without a formal contract (loss payouts had exceeded collected premiums for the group program). The Alabama REC now encourages licensees to seek coverage on the open market.

Rhode Island operates their mandatory program without the benefit of a contract with an insurance provider. Rhode Island had a contract with RISC from 1992 through 
2000; but, primarily because of the low number of $\mathrm{E} \& \mathrm{O}$ claims filed on licensees in the state, decided in 2000 to let RISC handle almost all of the program administrative details. This decreased the RECs administrative costs because the state government removed itself from the administrative process, but licensees can still benefit through a low group rate. In this case, RISC decided the loss experience was acceptable. Of course the Rhode Island REC is still responsible for ensuring licensee compliance with the mandatory E\&O provision.

6.3 Advantages and Disadvantages of Mandatory E\&O - In this section, the advantages and disadvantages of mandatory $\mathrm{E} \& \mathrm{O}$ programs, discovered by the researchers while conducting this study, are presented. Some are more subtle than others, and no guarantee is given that either list is complete. ${ }^{18}$ Comments made by REC survey respondents are presented in Exhibit 9.

\section{Advantages:}

Availability - Many insurance companies have stopped writing E\&O, or have greatly increased premiums, both of which make it more difficult for real estate licensees to obtain coverage. This topic was discussed at the ARELLO Annual Meeting in October 2003. Some real estate commissioners at this meeting reported that they could not even find an insurance provider willing to quote coverage at any price. However, the group

\footnotetext{
${ }^{18}$ Proponents and opponents of a mandatory E\&O system may believe that arguments for their viewpoint are missing. The researchers encourage anyone who has additional items for either list to contact them.
} 
program in each mandated state helps to make E\&O available to all licensees at affordable rates. ${ }^{19}$

Affordability - E\&O in the voluntary market is costly. Premiums for individuals often range from $\$ 300$ to $\$ 500$ or more, depending on the type of real estate activities performed. However, policies are generally only sold on a firm basis (i.e., the entire brokerage firm must purchase a policy and individual licensees do not have the option to obtain insurance). Minimum premiums for firm policies are in the range of $\$ 1,500$ to $\$ 2,000$. Many small companies may not be able to afford the minimum premium and therefore, go without coverage. Group plans under mandatory E\&O programs are designed to bring down the cost of E\&O (i.e., lower premiums and lower deductibles).

Portable Coverage - Mandatory E\&O programs alleviate another potential problem relating to individual coverage. Since E\&O is generally available to firms only, an individual who changes firms may find that he/she is not covered by the new firm's policy. Also, most firm policies cover claims against members of the firm for acts of a licensee only while the licensee is employed by that firm. For example, if an agent of Firm A is sued for an act which occurred while the agent was working for Firm B, Firm A's insurance may not cover this act. In addition, because some firms do not carry E\&O, a licensee working for that firm may be unable to obtain individual coverage. Group

\footnotetext{
${ }^{19}$ However, there was only one valid bid for every state soliciting bids in 2002 and 2003. In Colorado, there were two bids submitted for the 2004 program. However, the initially selected bidder withdrew its bid prior to policy inception, so there was only one valid bid. There were two bids received for Nebraska in June 2004 for its 2005 program and two bids received for Tennessee in July 2004 for its 2005 program.
} 
policies under mandatory programs are designed to provide individual coverage that will follow the licensee even if the individual changes firms.

Coverage For Prior Acts - Under mandatory programs, claims made during the policy period resulting from "prior acts" (a claim resulting from a transaction in a previous policy period, but where notice is not received until a subsequent policy period) are covered if the licensee has been in the group plan continuously from the date of the alleged error to the effective date of the claim. ${ }^{20}$ Prior acts coverage may also be available in the voluntary market, but would not apply if the licensee switched insurance carriers between the transaction date and the claim date.

Consumer Protection - The purchase of a home is the largest investment most consumers make in a lifetime. An undisclosed problem or misrepresentation, therefore, has the potential to result in a significant adverse effect for the consumer and, if the real estate licensee who caused the damages is uninsured, the consumer may be without recourse. Mandatory E\&O increases consumer protection from honest mistakes and omissions by real estate licensees because all licensees, not just some, are insured.

\section{Disadvantages:}

Increased REC Monitoring Costs - If a licensee covered by a state sponsored E\&O program experiences a lot of claims, the $\mathrm{E} \& \mathrm{O}$ provider is powerless to discipline the

\footnotetext{
${ }^{20}$ Officially, a claim is made when the insured first receives a written demand for money or services, or has received notification of a lawsuit or arbitration proceeding naming the insured.
} 
licensee. The licensee's policy premium cannot be increased and the insurer cannot drop a licensee from the group. In fact, there are only two ways the $\mathrm{E} \& \mathrm{O}$ provider can stop covering the licensee; 1) stop writing the entire group program, or 2) for the problem individual to no longer qualify as a group member (i.e., if he/she no longer has a valid license). Therefore, the REC must decide if it wants to police the program. An affirmative decision will mean the REC must absorb additional monitoring costs, and may require that the REC be (legally) able and willing to sanction licensees; even revoke a license if this action is justified. Such actions may not be politically appealing, but if somebody does not adequately monitor licensees and weed out the bad ones, responses to future RFPs are likely to include less attractive terms including higher premiums.

Additional REC Administrative Responsibilities - With a mandatory E\&O program, the REC will incur some, or all, of the Administrative responsibilities listed in section 6.4. In most cases, the REC must devote time and resources to the program to help ensure that it is operated effectively. This effort will involve coordinating the activities of REC administrators and staff with members of the state insurance and legal departments, which, in turn, will require these departments to also devote time and resources.

Things Might Get Worse - RECs in states that currently mandate E\&O are concerned with several issues: 1) that even with a group plan, premiums may escalate, 2) lack of participation by insurance companies acting as underwriters which limits competition and, at the extreme, could threaten the existence of the group program, and 3) that E\&O coverage encourages claims. 


\section{Exhibit 9}

\section{Comments Made by REC Directors}

\section{Advantages of Mandatory E\&O}

I recommend reading "Why Should a State with Mandatory E\&O Insurance Contract for a Group Policy?" The article was developed by Rice Insurance Services Company. However, it contains information and rationale that is consistent with Division policy.

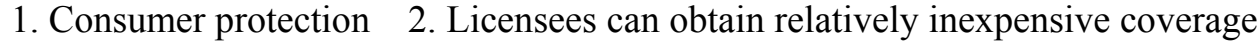

Good coverage at a reasonable rate. Prior to the implementation of mandatory E\&O, licensees were at the mercy of insurance companies, not since. In today's insurance climate with rate and coverage problems with all kinds of insurance, the group policy has proven its worth. Luckily we have been able to obtain coverage at a reasonable price. It also appears that the number of companies writing real estate $\mathrm{E} \& \mathrm{O}$ is declining. I had concerns that the companies were going to stop writing group plans so they could go back to setting rates and canceling on a whim. Interestingly, we received several calls in the year E\&O was mandated complaining about the requirement. In 2002 and 2003 we only received calls encouraging the commission to find a carrier at a reasonable rate and to continue the group plan. An equivalent policy could not be had for triple the premium and with deductibles ranging from $\$ 5,000$ to $\$ 10,000$.

Provides affordable policy to licensees. Ensures better protection for the public.

\section{Disadvantages of Mandatory E\&O}

Potential high premiums or lack of providers to carry coverage.

Tends to increase number of claims administratively only, and probably none after start up. Getting everyone in compliance and keeping track of those without coverage is about it. Going out for bid is not fun, but we get assistance from the insurance division and the attorney general.

None to licensee. Costs in man-hours to REC for compliance auditing, imposing fines for delinquent licensees.

None as regards the conceptual model. However, some proponents of litigation reform regard such professional liability insurance as a self-fulfilling prophecy. At first it seductively offers the appearance of a win-win solution; however the paradox is that over time, the existence of the program becomes the "pot of money" which lures the parties and their legal counsel to create more and more claims against the group program. Concern over escalating premiums and limited participation in professional liability by insurers, should prompt discussions between regulators, industry and insurers on measures (reform) to guard against the disappearance of the program.

\section{Problems with Mandatory E\&O}

None regarding the conceptual model. Concern over escalating premiums and limited participation in professional liability by insurers should prompt discussions between regulators and insurers on measures to guard against the disappearance of the program.

Verifying the coverage of licensees that do not take our coverage.

Lack of participation by insurance companies. 
6.4. Program Administration - REC survey participants were asked, "How much does it cost annually to administer the state mandatory E\&O program?" The responses suggest that some RECs may either not have a good grasp on this issue, consider administration costs to be too small to measure, or consider these costs to be a part of their overhead (5 RECs gave no response to this question). With few exceptions (i.e. the three states where the REC still collects the E\&O premiums), the majority of the administration duties have been transferred to the external program administrator (RISC). The primary duties maintained by the states in administering their mandatory E\&O insurance program are to: 1. issuing requests for proposals (RFP's) for new contracts; 2) reviewing bids; 3) negotiating final contracts; and 4) ensuring licensee compliance. Of those RECs which did respond to the survey question, the estimated costs of administering the E\&O program ranged from zero to $\$ 5,000$ annually. One state estimated the annual hours devoted to administrating the E\&O program to be 350 hours by the staff with an additional 100 hours by management. Special circumstances may result in extra administrative costs. For example, in Kentucky there is a tax on insurance that varies by county so in collecting the E\&O premium the REC must verify the licensee's county of residence to ensure that the correct amount of tax is collected.

The contracting process varies from state to state; however, in general, the REC with the assistance of the legal and/or the insurance departments issues an RFP for a contract administrator who will be responsible for obtaining an insurance carrier. The contract term may vary (in most cases, from one to three years with options for extensions). 
6.5. Policy Terms \& Associated Regulations - In 2004, Rice Insurance Services Company, LLC of Louisville, Kentucky (RISC) was the exclusive contract administrator; servicing all states with mandatory E\&O programs. ${ }^{21}$ The information contained in Exhibits 10 and 11 was provided by RISC and state RECs. Examination of the information presented in Exhibit 10 will reveal considerable variation between states regarding policy terms and associated requirements. While the maximum coverage per claim, shown in the second column, is $\$ 100,000$ in every state; the total claim limit, shown in the third column, ranges from $\$ 100,000$ in Iowa to $\$ 1,000,000$ in Kentucky. ${ }^{22}$ However, licensees in each state are allowed to obtain additional coverage from RISC (or other insurers). The total deductible amount per claim, shown in the fourth column, ranges from a low of zero in Iowa and Kentucky to $\$ 2,000$ in Mississippi, North Dakota and Rhode Island.

Seven states have statutes or rules, shown in the fifth column of Exhibit 10, which set an upper limit on the annual premium amount. The limit ranges from $\$ 125$ in Kentucky and North Dakota to $\$ 500$ in Louisiana and Nebraska. In the past, such limits have presented a problem in some states as market conditions drove premiums above the previously set limit. This problem cannot occur in the five states that have not set a premium limit. Actual premiums charged (to be charged) in 2004 (2005) are shown in the sixth column of Exhibit 10. The annual premium for 2004 ranges from $\$ 80$ in Rhode Island (where claims have been incredibly low - see Exhibit 11) to \$230 in Colorado.

\footnotetext{
${ }^{21}$ RISC will also be providing service to all but Nebraska, which is switching to Williams Underwriting Group, in 2005.

${ }^{22}$ The limit on the number claims that may be filed on an insured licensee is a function on the dollar payments made on claims against the policy. For example, a single $\$ 100,000$ claim would exhaust the coverage of a licensee in Iowa, but 20 claims of $\$ 5,000$ each would be covered by another licensee in that state.
} 
The rightmost column in Exhibit 10 shows that the state REC collects the premium in three states: Kentucky, Louisiana and South Dakota. RISC collects the premium in the other nine states. In all cases, the state REC has ultimate responsibility for ensuring that each licensee is in compliance with the mandatory $\mathrm{E} \& \mathrm{O}$ requirement.

Policy premiums are a function of a number of variables, including: the number of individuals in the group, loss experience, deductible amounts, and exclusions. Exclusions are not shown in Exhibit 10 because there are few (but some) differences in policy exclusions between the subject states. Generally, the exclusions in mandatory program policies are similar to those in non-mandatory policies, and include transactions where the licensee had a personal interest, the claim was not submitted by the insured to the insurance company during the coverage period, fraud or a crime was involved, environmental conditions are involved, and where the insured is alleged to have caused personal injury.

The data in Exhibit 10 enables a rough estimate of the premium that might apply to Ohio licensees in a group program (with terms similar to those of existing programs) in 2005. Toward this end, a univariate approach was employed. A 95\% prediction interval was calculated to specify a range of the policy premium for Ohio licensees. This calculation was based on the policy premiums that apply in 2005 for each of the twelve states with a mandatory program. The prediction interval is from $\$ 61$ to $\$ 233 .^{23}$

${ }^{23}$ A prediction interval differs from a confidence interval in that the prediction interval specifies the range within which a new individual measurement is expected to fall. A second prediction interval was estimated based upon a bivariate regression relationship: premiums in the states with mandated $\mathrm{E} \& \mathrm{O}$ and number of licensees participating in the mandated program. Given the number of Ohio licensees and an assumed participation (in the group plan) rate of $75 \%$, the prediction interval ranged from $\$ 122$ to $\$ 303$. The result is sensitive to the assumed licensee participation rate. In making this estimate only a single bivariate relationship was used because the small number of states in our study limits the number of independent variables that can be simultaneously examined. For each additional independent variable, a degree of freedom is lost in the error term making it difficult to detect a significant relationship. 
As mentioned in section 4, some licensees believe that the E\&O claim limits, detailed in Exhibit 10, are too low. However, the $\$ 100,000$ per claim limit that currently applies in all mandated states is more than fivefold the average paid claim amount shown in Exhibit 11. ${ }^{24}$ In addition, in some cases, the effective claim limit for the consumer is greater than the limit specified in Exhibit 10. For example, if two (or more) licensees are involved, the consumer could collect up to $\$ 200,000$ (a higher amount). Finally, it is worth emphasizing that a licensee can obtain additional coverage.

In section 3, it was mentioned that Ohio has reciprocity agreements with four states which currently mandate E\&O. Participants in existing state sponsored E\&O programs can obtain coverage in all states with which their state has reciprocity by paying a single $\$ 15$ endorsement. As long as the licensee's home state policy meets the minimum E\&O requirements of the other state, the licensee is then able to operate in the other state. The same would apply to Ohio licensees.

\footnotetext{
${ }^{24}$ In making this observation, the researchers are aware of the story of the 6 foot tall man who drowned in a river with an average depth of two feet. In addition, Iowa's $\$ 100,000$ total claim limit may not provide adequate protection for multiple claims.
} 


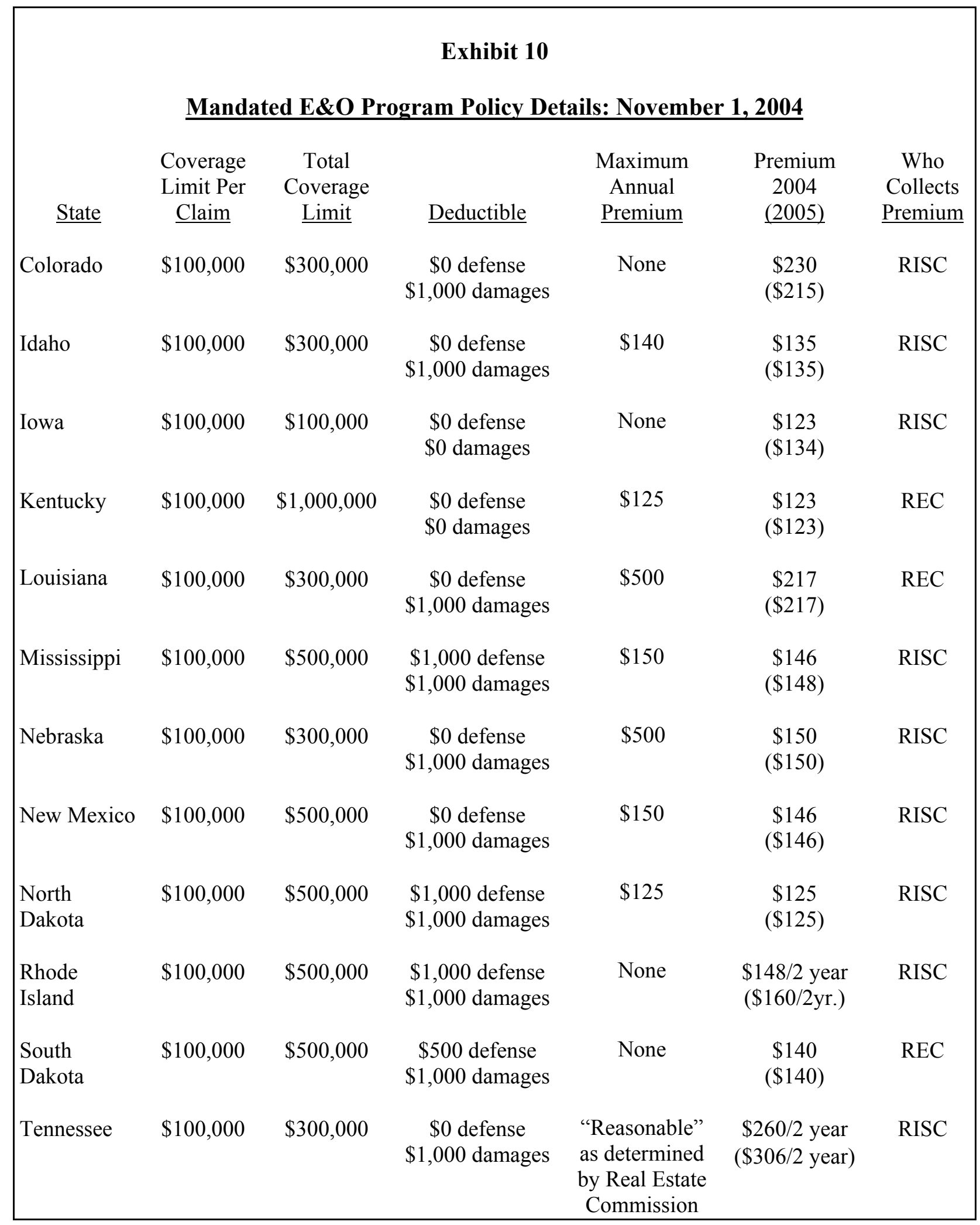


6.6. Recent Claim Activity - The 2001-2003 claim history for state sponsored E\&O programs is summarized in Exhibit 11. During this period, the number of annual claims ranged from only 4 in South Dakota during 2003 to 598 in Colorado during 2001. The average claim amount paid ranged from $\$ 4,705$ in Nebraska during 2002 to $\$ 20,963$ in Colorado during 2003. The total claims paid ranged from $\$ 16,723$ in North Dakota during 2002 to $\$ 4,469,194$ in Colorado during 2002. Examination of the data for all states reveals no clear trend in either: number of claims filed, average claim amount paid, or total claim amount paid. Note that the average claim amount paid for all states is well below the $\$ 100,000$ per claim limit detailed in Exhibit 10. However, the defense deductible that applies under four state programs (Exhibit 10) can still be costly for licensees. Fortunately, the probability is low that a licensee will be involved in a claim. The ratio of "total number of claims in 2003" (from Exhibit 11) to "number of licensees in the state sponsored program" (from Exhibit 2 and footnote 12) was calculated for each state (e.g., for Mississippi: 68 claims/5,604 licensees). The unweighted average ratio for all mandatory E\&O states (except New Mexico where claim information was unavailable) indicates that, for the year, the probability of a licensee in a state sponsored program being involved in an E\&O claim was $1.2 \%$. 
Exhibit 11

Annual E\&O Claim Information: 2001-2003

\section{Claims}

No payment or reserve

With payment or reserve

Total Claims

Average claim amount for

claims with payment or reserve

\section{Claims}

No payment or reserve

With payment or reserve

Total claims

Average claim amount for

claims with payment or reserve

\section{Claim}

No payment or reserve

With payment or reserve

Total claims

Average claim amount for

claims with payment or reserve

2001 Total paid \& reserve

2002 Total paid \& reserve

2003 Total paid \& reserve

Key:

$\mathrm{NA}=$ not available

$\mathrm{NM}=$ Program not mandated this year

Source: RICC Insurance, and various state regulators
New

New North South Rhode

$\underline{\text { Colorado }} \underline{\text { Idaho }} \underline{\text { Iowa }} \underline{\text { Kentucky }} \underline{\text { Louisiana }} \underline{\text { Mississippi }} \underline{\text { Nebraska }} \underline{\text { Mexico }} \underline{\text { Dakota }} \underline{\text { Dakota }} \underline{\text { Island }}$

Tennessee

$\begin{array}{rcccccccccccc}370 & 7 & 49 & 32 & \text { NA } & 29 & \text { NA } & \text { NM } & \text { NM } & 9 & 2 & 87 \\ 228 & 11 & 42 & 40 & \text { NA } & 35 & \text { NA } & \text { NM } & \text { NM } & 13 & 6 & 84 \\ 598 & 18 & 91 & 72 & \text { NA } & 64 & 74 & \text { NM } & \text { NM } & 22 & 8 & 171 \\ \$ 18,509 & \$ 8,054 & \$ 6,791 & \$ 8,990 & \text { NA } & \$ 18,426 & \$ 5,427 & \text { NM } & \text { NM } & \$ 13,167 & \$ 14,917 & \$ 10,497\end{array}$

$\begin{array}{llclll}343 & 23 & 62 & 34 & \text { NA } & 32 \\ 238 & 16 & 50 & 42 & \text { NA } & 31 \\ 581 & 39 & 112 & 76 & \text { NA } & 63\end{array}$

$\begin{array}{ccccccc}32 & \text { NA } & \text { NA } & 5 & 6 & 8 & 72 \\ 31 & \text { NA } & \text { NA } & 1 & 10 & 5 & 93 \\ 63 & 61 & \text { NA } & 6 & 16 & 13 & 165 \\ & & & & & & \\ \$ 15,245 & \$ 4,705 & \text { NA } & \$ 16,723 & \$ 6,186 & \$ 2,981 & \$ 8,809\end{array}$

$\$ 18,778 . \$ 11,540 \quad \$ 12,957, \$ 13$$$
\$ 15,245
$$

$$
\$ 4,705
$$

$\begin{array}{ccccc}401 & 19 & 41 & 35 & 63 \\ 162 & 25 & 61 & 83 & 99 \\ 563 & 44 & 102 & 118 & 162\end{array}$

30
38
68

NA
NA
43

NA
NA

$\begin{array}{ccccc}\$ 20,963 & \$ 11,255 & \$ 6,895 & \$ 8,549 & \$ 11,220 \\ \$ 4,220,092 & \$ 88,596 & \$ 285,201 & \$ 359,610 & \text { NA } \\ \$ 4,469,194 & \$ 184,643 & \$ 647,844 & \$ 365,965 & \text { NA }\end{array}$

$\$ 11,145$

$\$ 8,782$

NA

$\$ 644,918 \$ 401,598$

$\$ 472,607 \$ 287,005$

$\$ 3,396,014 \quad \$ 281,365 \quad \$ 420,572 \quad \$ 709,581 \quad \$ 1,110,745 \quad \$ 423,521 \quad \$ 377,626$

$\begin{array}{ccccc}\text { NA } & \text { NM } & \$ 79,000 & \$ 193,919 & \$ 881,734 \\ \text { NA } & \$ 16,723 & \$ 30,930 & \$ 29,805 & \$ 819,280 \\ \text { NA } & \$ 40,847 & \$ 23,669 & \$ 80,674 & \$ 1,219,898\end{array}$




\section{Implementation of Mandatory E\&O: Lessons from Existing Programs}

In this section, several procedural issues that should be considered by state officials contemplating a mandatory E\&O program are presented. First, it is best to keep statutory requirements as basic as possible because circumstances may change and it is sometimes problematic to amend statutes. To facilitate this effort, statutes from states with mandatory programs (which vary in the amount of detail) should be examined when formulating proposed legislation. Most state statutes provide that the REC shall determine the terms and conditions of coverage, including claim limits, deductible amounts, and policy exclusions, through Rules and Regulations. This is an effective method which may ease program administration if future changes in these items are required. Rules and regulations tend to be easier to modify compared to statutes.

Second, despite the fact that the statutes of most states with mandatory E\&O specify a maximum policy premium (Exhibit 10), such a specification is not recommended. A statutory price limit can create problems in the event the statutory premium ceiling becomes unrealistic due to changes in market conditions. In fact, this problem has already occurred in more than one state, necessitating an amendment to the statutes. Again, greater flexibility is available when the statute gives the REC the authority to set a maximum premium which can be adjusted to account for inflation or a change in market conditions.

Third, specifying a minimum A.M. Best rating requirement by statute is not recommended. There are often only one or two bidders for mandated E\&O programs and restrictive rating requirements in the statute may further limit competition. In an effort to 
ensure financial stability of its insurance carrier, two states established a minimum A.M. Best rating requirement by statute. Most states, however, do not include this item in their statutes. Instead their legislation allows the REC to either establish the minimum rating requirement in the RFP specifications or to consider the company's rating as a factor when evaluating the bid proposals. ${ }^{25}$

Fourth, if the state has a real estate recovery fund in place (as in Ohio), it is recommended that the recovery fund be maintained to protect the public for legitimate claims that either exceed E\&O policy limits or claims that are excluded by the E\&O policy. However, at the time mandatory E\&O is being contemplated, it is important to consider the interaction of allowable claims and claim limits for both the recovery fund and $\mathrm{E} \& \mathrm{O}$ program. Upon implementation of mandatory $\mathrm{E} \& \mathrm{O}$, several states in our sample modified their recovery fund claim limits or criteria.

Fifth, licensees should have the option to obtain coverage independently so long as the coverage at least meets state requirements, and sixth, mandatory E\&O should only apply to active licensees. All states with mandatory E\&O follow both of these prescriptions. Without the later, licensees considering temporarily leaving the business would have an incentive to drop their license rather than transferring it to inactive status.

Finally, during the program investigation phase, regulators should make it clear to all parties exactly why the move is being contemplated (e.g., lower premiums, consumer protection). In addition, regulators should encourage, and seriously consider, licensee input on the proposal.

\footnotetext{
${ }^{25}$ In all process phases (e.g., drafting legislation, formulating Rules and Regulations, and drafting RFPs), a good resource is the state's Risk Manager. As an expert on insurance issues, input from the Risk Manager can be helpful (e.g., establishing reasonable coverage terms, and assisting in the evaluation of the financial strength of bidders).
} 


\section{$\underline{\text { References }}$}

Abelson, L., K. Kacmar and E. Jackofsky, Factors Influencing Real Estate Brokerage Sales Staff Performance, Journal of Real Estate Research, 1990, 5, 265-275.

Coleman, J. and J. Larsen, The Impact of Hardening in the Homeowner's Insurance Market on Ohio Residential Real Estate Brokerage Markets. Research Report 2004-10. Ohio Department of Commerce, Division of Real Estate \& Professional Licensing. Crellin, G., J. Frew and G. Jud, The Earnings of REALTORS: Some Empirical Evidence, Journal of Real Estate Research, 1988, 3, 69-78.

Glower, M. and P. Hendershott, The Determinants of REALTOR Income, Journal of Real Estate Research, 1988, 3, 53-68.

Larsen J. and J. Coleman, Factors Associated with Survival of New REALTOR ${ }^{\circledR}$ Associates in Ohio, Journal of Real Estate Practice and Education, 2003, 6, 163-190.

Larsen, J. and J. Coleman, Psychologically Impacted Houses: Broker Disclosure Behavior and Perceived Market Effects in an Unregulated Environment, Journal of Real Estate Practice and Education, 2001, 4, 1-16.

National Association of REALTORS ${ }^{\circledR}$, The 2003 National Association of REALTORS ${ }^{\circledR}$ Member Profile. Chicago, IL.

Sirmans, G. and P. Swicegood, Determinants of Real Estate Licensee Income, Journal of Real Estate Research, 1997, 14, 137-154.

Sirmans, G. and P. Swicegood, Determining Real Estate Licensee Income, Journal of Real Estate Research, 2000, 20, 189-204.

Stitz, G., 2004 Ohio Association of REALTORS ${ }^{\circledR}$ Member Survey Findings, 2004, Ohio Association of REALTORS ${ }^{\circledR}$, Columbus, Ohio. 